\title{
THE USE OF ENGLISH AS A LINGUA FRANGA IN TRANSLATION
}

\author{
J.A. Foley and M.F. Deocampo \\ Graduate School of English, Assumption University \\ jfoley@au.edu
}

First received: 19 November 2014

Final proof received: 21 Januari 2016

\begin{abstract}
In translation, not only two languages but two cultures come into contact which means that translators must consider who wrote the text, when, why, for whom and who is now reading it and for what purpose. In the wake of rapid technological advances and the need to spread information quickly and efficiently, translation has grown in importance in the globalized world. So has its reliance on English in its role as a global lingua franca. English is often being used for 'interculturalizing' native languages but it is also true that English texts are written by speakers who use English as a lingua franca (ELF) with the additional consequence of local languages being incorporated into the texts. This is the linguistic hybridity used in constructing a wider view of the world. However, the prime aim of any lingua franca communication is mutual intelligibility. Saussure wrote about the contrasting principles of provincialism (ésprit de clocher) and what he termed intercourse: the need for broader communication. We can see Saussure's principles as two imperatives: the cooperative and territorial imperatives. That is to say that language change is brought about by the 'cooperative imperative' as we need to continually modify our language in order to communicate with other people. At the same time, there is the 'territorial imperative' to secure and protect our own space and sustain our separate social and individual identity. In this study, the translation of linguistic units can only be understood when considered together with the cultural contexts in which they arise, and in which they are used. Blogging in Singapore and the Philippines is part of the 'cooperative and territorial imperatives' where the use of English as a lingua franca is intertwined with translanguaging.
\end{abstract}

Keywords: EFL, translation, cooperative and territorial imperatives, translanguaging, blogging, Singapore, Philippines.

Translation can be defined as the result of a procedure in which a text in one language is recontextualized in another language. Translation, however, is subject to a variety of extra-linguistic factors and conditions and this is what makes translation such a complex phenomenon. Translation is therefore not only a linguistic act but an act of communication across cultures (Nida, 1964). As language is culturally embedded: it serves to express and help shape cultural reality. In translation, therefore, not only two languages but two cultures invariably come into contact. In this sense translation is a form of intercultural communication; where the translator must consider the immediate 'context of situation'. This more local situational context has to do with questions about who wrote the text, when, why, for whom and who is now reading it and for what purpose. These questions, in turn, are reflected in how a text is written, interpreted, read and used. Exploring text in context is the only way of exploring text for the purposes of translation as re-contextualized texts travel across time and space (House 2012, 2015).

In the wake of rapid technological advances and the need to spread information quickly and efficiently, translation has grown in importance in the globalized world. So has its reliance on English in its role as a global lingua franca. An important area in the study of globalized intercultural discourse concerns computer mediated communication and internet domains. Consequently, there is an influx of words in the discourse on the internet which may be English or from other languages that fill a lexical gap and are placed to achieve certain effects. It is true that the English language is often being used for 'interculturalizing' native languages but it is also true that English texts are written by speakers who use English as a lingua franca (ELF) with the additional consequence of local languages being incorporated into the texts. This is the linguistic hybridity used in constructing a wider view of the world. However, it is not only this 'interculturalization' that is involved but since the prime aim of any lingua franca communication is mutual intelligibility, correctness in terms of formal 'native speaker' discourse tends not to be such an absolute criterion (Cogo and Dewey 2012:59). Culturally embedded linguistic forms such as idioms with routinized phrases associated with culturalhistorical references may be very difficult to translate in the target language. Thus an advantage of ELF is the spread across many different linguistic, geographical and cultural areas, as well as the readiness with which linguistic terms from different languages are and have been integrated into the English language (Firth 2009). To add to 
this is the now well established fact that users of ELF are substantially larger than the number of native speakers of English such that English as its role as a global lingua franca can be said to be no longer 'owned' by its native speakers (Widdowson 1994, Seidlhofer 2011).

However, ELF is not 'foreigner talk' nor does it fit the 'Interlanguage' paradigm with its focus on the linguistic deficits of learners of a foreign or second language measured against native speaker norms. ELF speakers are not regarded as learners of English, but as multilingual individuals with linguistic-cultural 'multicompetence'. It is this multicompetence which needs to be taken as the norm for describing and explaining what ELF speakers do in communicative acts of speaking, and writing.

One can pose the question whether the increased use of ELF might even reduce the need for translation. However, translation seems to be playing an even greater role in international networks, television, the internet, social media and blogging. The expansion of digital industries around e-learning and other education forms in many different languages shows the strong link between translation and globalization (Cronin 2003). It could be well argued that translation is not simply a byproduct of globalization, but an integral part of it. Yet, there is an assumption that underpins this and that is that translators should adhere to the expectations of native English readers, rather than those of readers using English as a lingua franca.

It will be argued here, that globalization has brought about a concomitant rise in the demand for texts that are simultaneously meant for recipients in many different languages and cultures, in other words, part of the 'communicative imperative'. This is particularly true in texts used in social media where the mixture of local varieties of English and local languages are used in contexts characterized by unequal power relations between individuals, groups, and languages. In these contexts, translation does not function only as a conflict mediating and resolving action but also as a space where tensions are signaled and power struggles are played out (Baker 2006). It is in this field of globalized discourse that computer-mediated linguistic plays an important role in terms of lexis, semantics, pragmatics and at the socio-semiotic level. Canagarajah (2007) pointed out that since cultures are hybrid and dynamic, negotiation and accommodation processes tend to be set in motion in any text production. At the socio-semiotic level, intercultural globalized discourse has been described as an assemblage of 'globalized linguistic signs' that lead to the creation of new globalized multilingual landscapes (Gorter 2006). In this study, Singapore and the Philippines will be used to exemplify how on-line discourse in Southeast Asia is employed using varieties of English that are intertwined with local languages.

\section{The linguistic background}

A century ago, Ferdinand de Saussure (1914/1959) wrote about the contrasting principles of provincialism (ésprit de clocher) and intercourse. On one hand, as he argued, provincialism keeps a community faithful to its traditions and encourages cultural continuity. On the other hand, there is an opposing force, the need for broader communication for which Saussure used the English word intercourse. What this reflects is a tension in desires to retain something local, traditional, or 'authentic' in the provincialism while incorporating matters of pluralism, assimilation, as well as linguistic practicality and communicative efficiency for social mobility.

We can re-formulate Saussure's two forces as the cooperative and territorial imperatives. That is to say that language change is brought about by the 'cooperative imperative' in that we need to continually modify our language in order to communicate with other people. However, at the same time, there is this tendency to have an element of compliance in our language that is the 'territorial imperative' in order to secure and protect our own space and sustain our separate social and individual identity. The current focus on ELF research is directed at identifying what ELF 'norms' (the cooperative imperative) consist of. In other words, what sort of forms do competent ELF speakers systematically, and frequently produce that are both communicatively effective and different from the norms of native speaker (NSs) users of 'standard' English.

Whereas, Territorial Imperatives are by their nature more 'localized' and reflected more in the lexis as in the following examples:

- Singapore and Malaysian English Kelong: He kelonged us. (cheated)

$\mathrm{He}$ is so kiasu. (always wants to have something better than you)

So blur blur like sotong. (someone very stupid or inept)

'chap sat tiam' (thirteen o'clock) meaning incompetent

- Philippino

Carnapping (stealing cars)

Malling (shopping in department stores but not necessarily buying anything)

Salvage (kill in cold blood).

ELF as a form of English exists because it reflects the needs and aspirations of the evergrowing number of NNS who use English to communicate with other NNS. ELF also has to focus on pragmatic strategies required in intercultural communication. Consequently, a translator in such a lingua franca context would often be an English 
knowing bilingual, with an ability to code-switch in terms of a language continuum pertaining to both features of the 'Territorial Imperative' and the 'Cooperative Imperative'.

\section{Background \\ Singapore}

The use of English in Singapore has been well documented by Tongue, 1974, Crewe, 1977, Platt and Weber, 1980, Foley, 1988, Foley,1998a, Foley et al.1998b, Foley 2006, , Gupta, 1998, Lim, 2004, Low and Brown, 2005. Low and Brown (2005) described the domains of use of the 'Cooperative Imperative' or Singapore Standard English (SSE) as follows:

- an official language

- a language of education

- a working language

- a lingua franca

- a language for expression for national identity

- an international language

Singapore Colloquial English (SCE) or the 'Territorial Imperative' on the other hand has been described as having the following lexicogrammatical features (Gupta 1998, Low and Brown 2005, Lim 2004 and Foley 2014):

- It contains pragmatic particles such as lah, lor, meh, and what [ubiquitous tags used like full stops but can have different meanings according to the context as for example meh would add a tone of incredulity and lor would indicate a more resigned tone than lah] "Did you put my book in other shelves? No lah! I did not."

- It contains verb groups without subjects

"Late for your class already."

- Conditional clauses without subordinating conjunctions

"You sing like that, surely you will lose."

- -ing as a finite verb, and verb less complements

"Yes, I _ going with you, so wait for me."

- Reduplication of adjectives

"Which one do you like? That one, the green-green one."

- Limited forms of the question tag

- "Eh, when you write essay that time, can cut down cheeminology or not?

- "Aiyoh![exclamation of annoyance] Forgot to pass your paper is it?”

- "Eat orreedy is it? Go lah!"
In a multicultural and multi-ethnic country like Singapore, it is common to hear people speak different languages and they tend to accommodate to each other's level of language. Borrowings and inference from other background languages are an essential part of Singapore English, and have had an influence especially on 'Singapore Colloquial English as it has become very much a marker of identity.

- Alamak![exclamation of incredulity] Masuk [let in] two goals already. I'm $\underline{\text { habis }}$ lah! [I'm finished!]

- Adoi![exclamation with a lesser degree of exasperation than Alamak ] You ketok knock] my head for what, pain you know.

- That auntie so kiasu, [afraid of losing] cannot tahan [tolerate] her attitude.

- Aiyoh why you're so kaypoh,[nosey parker] see lah it's sala [wrong] already.

- Why you are so goondu, [stupid] you see now it's koyak. [broken]

\section{Political and Economic context}

Singapore, as one of the economic powerhouses in Southeast Asia has embraced a 'hybrid' form of government, partly autocratic and partly democratic. This form of governance has contributed to its success as well as many of the issues the city state has to face. One of the present issues is that of new immigrants coming into the country. Historically, immigration is not a new phenomenon in Singapore but the present policy is to grant immigrant status to those who could contribute to the socioeconomic development of Singapore. The strategy was originally developed to attract a talented labor force that could assist in providing mainly economic success for Singapore (Wee, Goh \& Lim 2013).

There are two categories of population in Singapore; the citizens (natural born citizens) and permanent residents (PR) while those who are in Singapore temporarily such as students and overseas worker are given the status of 'non-residents'. PRs are immigrants who have been approved to settle in Singapore permanently, and have the right to avail themselves of government subsidies especially housing and education.

George (2012) writing about the concept of government in Singapore described governmental policies as 'calibrated coercion' that is, subtle ways to subvert freedom of expression and to entrench power. Public dissent is effectively only possible through the anonymity of online discourse. One of the 'open source platforms', the Yahoo News sites offers the possibility of blogging, in order to share views and reactions, typically on such topics as immigration, education, and employment.

Extract $1 \mathrm{~S}$

To me, these tution* (tuition) grants are so easily available to the foreigners mainly to engage them in Singapore. Bond them to work here for 
minimum years, then give them PR \& Citizenship. Another clever way to source and secure for new immigrants indirectly.

BUT does the males around 18-25 needs to serve NS when they convert as Citizens?

Does WHITE HORSEs IN NS EQUAL TO THE COMMON SONS of SINGAPOREANS in terms of TREATMENTS in the Military????

\section{NOTHING is EQUAL in LIFE when GREEDs is concerned.}

\section{Extract $2 \mathrm{~S}$}

I heard from a friend that he applied for 华社 (Xinhua News Agency) help, but when they saw that he got TV at home, rejected his application saying that since he can afford TV, he is not eligible for financial assistance. Financial assistance post too many restrictions and are not flexible.... thereby saving millions and into the pockets of Miws...

\section{Extract $3 \mathrm{~S}$}

they say science and engineering course got more intake because Singaporean dun wan. That's all bullshit.

Even if JC student dun wan, but every year there are so many Poly student applied to go into local university's engineering course, but rejected.

$\mathrm{u}$ shld appeal under the case where yr son is going to study arts in an overseas institution..then if he is lucky he may get 12 yrs exemption but of cos yr son need to come back $\mathrm{n}$ serve out his duty...in a science lab probably...:)) :))

(Deocampo 2014)

The above samples are fairly typical of the language used and because it is informal and have several features of SCE as indicated by the underlining. But as well as SCE there are often other features of language that require more cultural 'filtering' in 'translating' the texts for readers outside the Singapore/Malaysian speech community. Samples of the language used would be the following.

The use of discourse particles function like full stops in the spoken language but the tone can indicate a different meaning or attitude,

Why study so ${ }^{\wedge}$ hard lor? [cynical]

'... our education system not ${ }^{\wedge}$ working lah!'

'^alamak! like that how huh?'

'... work in hawker centres and ^cleaning toilets meh?[incredulity]

'...Sir can't be ^helped leh' [quizzical tone]

'...now Mata (Police) wear ^long pants liao lor' [already]

'...you are the ones 'complaining mah' [incredulity]

‘...Long time no ${ }^{\wedge}$ see hor [another tag indicating punctuation]
The use of repetition or reiteration of word as an intensifier

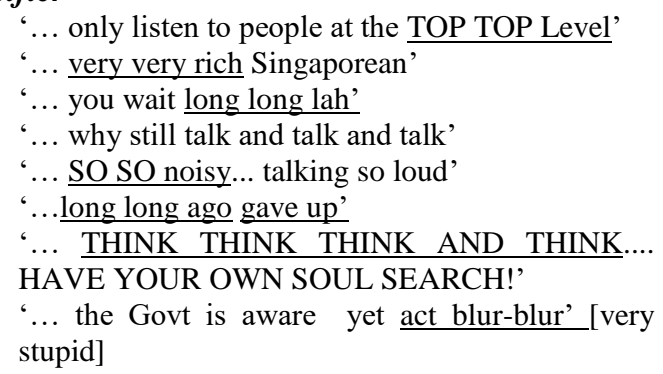

\section{Translanguaginging}

Garcia and $\mathrm{Li}$ (2014) have used this term as an approach to the use of language in multilingual settings that considers the language practices not as two autonomous language systems, but as one linguistic repertoire with features that have been societally constructed as belonging to two separate languages as in the following:

the employers will usually 'siam' [console]

'... at least understand out language! If not balek kampong [go back to your village]'

'... birthday celebrations and makan [eating] sessions, I was left behind'

'... shiok, [good] if golden age employment

'... will be very pleasantly viewed . you chikopek [dirty old man]!!!'

'... not a good sign Singapore become a 优雅社

会 [elegant society] with all these people'

'... Our land has become a rozak [mixed]'

Buay song lio [no more fun] si buay song [so much fun]! Nothing to hide!'

'... the chinese saying "Boh Hee, Hay are $\underline{h o}$ ![everything goes]'

'... kow pay kow boo [make to much noise] for what?'

'... Blood suckers ! Bumalik sa iyong bansa [go back to your country]'

'... cannot tahan [cannot take it] with this PINOY [Filipino] when they are in groups'

'...Chinese not obedient but generally Kiasi, [afraid of death] Kiasu, (afraid of losing) $\underline{\text { Kia tio }}$ kan [afraid to be scolded].

‘...万岁万岁万万岁 [long live, long live, long long live] to our Lee

“政府一直说有两党的国会对人民不利? 你相信 ? 现在你们看到了, 46 年的一党政策, 我们失 去很多，孩子没了，老了没人照顾了。。。

。伤心,

[The Government has said that there is bipartisan congressional detrimental to the people? Do you believe that? Now you see, 46 years of one-party policy, we lose a lot of kids did not, no one to take care of the old. .... Sad]

(Deocampo 2014)

Blogging using the diglossia of English in Singapore, that is SSE and SCE often interspersed with local languages mainly Malay and Hokkien, 
can make considerable demands on the process of translation. The target, however, is not superimposed norms of British or American English on other languages but a hybrid text that allows for a co-existence in the translation of a multilingual text.

\section{The Philippines}

The Philippines is a large archipelago that consists of more than 1,700 islands, different ethnic groups as well as more than 175 local languages and as many as 500 community dialects. Apart from the Philippines' own rich variety of languages, it had been under the colonial rule of Spain for 330 years, the United States for more than 50 years, until the end of WWII and the defeat of Japan in 1945.

Indeed it can be said that the widespread use of English in the Philippines is the most important legacy left over from the colonial days. By the 1930's, English was well established as the language of education, business, law, industry and government (Henderson 2002). Indeed Filipinos were traditionally seen as probably the most efficient user of English in Asia (Sunga 2003). However, this situation has changed, students in particular feel more at ease with Filipino. One major factor that has been blamed for the decline of English was the adoption of the Bilingual Education Policy (BEP) in 1970. The policy required instruction to be given in Filipino with only English in science and mathematics. However, Sibayan and Gonzalez (1996), Pena, (2000), claimed that there was no consistent correlation between the years of implementation of the BEP and the students' scores in English. But there was an influence that did change the status of English in terms of acceptance and use, and that was the introduction of Taglish. This is a combination of Tagalog, English and Spanish and is found predominantly in domains which include education, business, religion and entertainment. Related to the issue of Taglish was the move to encourage use of Filipino in government and education (Son 1998). However, English still remains significant as a lingua franca, because of the economics of using English in a global context (Castillo, 2003).

\section{Standard Philippine English (SPE)}

D'Souza (1998 quoted in Sunga 2003) said 'should be widespread and systematic, rule governed and used by competent users in formal situations' and when we look at the details, in particular the grammar of SPE with, for example SSE is quite striking. We can see this in the following examples:

- The loss of the singular inflection of verbs The family home rest on the bluff of a hill. One of the boys give a report to the teachers every morning.
- Use of present perfect for simple past and past perfect for present perfect

I have seen her yesterday. (I saw her yesterday)

He had already gone home. (He has already gone home.)

- Use of continuous tenses for habitual aspect $\mathrm{He}$ is going to school regularly. (He goes to school regularly)

- Use of the present forms of auxiliary verbs in subordinate noun clauses rather than past forms and vise versa.

He said he has already seen you. (He said he had already seen you.)

She hoped that she can visit you tomorrow. (She hoped that she could visit you tomorrow)

- Reversal of norms for the use of the definite article.

He is studying at the De la Salle University. I am going to visit United States.

- Verbs that are generally transitive used intransitively

Did you enjoy?

I cannot afford.

I don't like

(Bautista, 2000:34-35)

Other features we would term the territorial imperative.

- Philippine English has many borrowed or loan words either from Tagalog or Spanish. For example, words like carabao [water buffalo], merienda [mid-morning or afternoon snacks], querida [mistress], and despedida party [farewell party]. Loan translation is also presented in Standard Filipino English [SFE] or the cooperative imperative. A phrase such as open the radio instead of turn on the radio is also used in other electrical appliances. Other words such as bold [semi-nude], jingle [urinate] and neologisms like: comfort room [CR or washroom/toilet], bed-spacer, [a person who rent a bed in dormitory], hold-upper, [someone who is engaged in armed robbery], presidentiable, [a possible candidate for a president], jeepney, [a customized extended jeep used for transportation]. Such development of new words has resulted in the increased use of Filipino-English or Taglish, and become an informal discourse of educated Filipino.

Due to the close relationship between Filipino and English and some similarities in terms of grammar, it is common for Filipinos to switch from one language to another such as Tagalog and English or what is called Taglish. Sibayan (1978) 
noticed Taglish being used in the late 1960s and Marasigan (1983) noticed it in newspapers in 1967. Mixing Tagalog and English has become so widespread in Metro Manila that it is hard to say what the home language is, since educated people in Manila learn English in the home as a second language (Llamzon and Lee 1980). In essence, "Taglish has become an auxiliary spoken language with no formal body of literature except in newspapers and usage by educated Filipinos." (Sibayan, 1994:220).

For example:

Taglish: 'Grabe! Ang bagal naman ng bus na 'to! [Gosh! This bus is so slow.]

Taglish: Puwedeng humiran ng ballpen mo? [Can I borrow your ballpen?]

Taglish: O, ngayon, do you believe what I say na? [rejoinder] Now, do you believe what I say [tag]

Taglish: Hay 'naku, napaka unlucky naman $n g$ day $k o$ !

Hay [sigh,feeling of frustration] mother me, what an unlucky day I have!]

Taglish: Gusto sana naming manood ng movie mamaya kaso lang late matapos ang work ng friends namin. Kaya, ito nagsashopping nalang, boring kase.

[We actually would like to watch a movie later but our friends will finish their work late. So, I'm here shopping because it's boring.]

(Deocampo, 2011)

The popularity of Filipino-English in the media is one of the reasons why Taglish is becoming widespread. Many examples can be found in magazines and newspapers or interviews and panel discussions on television. The diaspora of overseas workers from the Philippines who come from different linguistic backgrounds have made Taglish their 'lingua franca'.

The following are some examples of blogging on 'education and government' issues.

\section{Extract $1 \mathbf{P}$}

Fast emerging? Million+ mga Pilipino ang di makatapos ng pag-aaral dahil ninanakao ang pera ng taumbayan ng $m g a$ buwaya Tapos yung ibang mga Koreano, sila pa'ng racist dito sa bansa natin. [translation: More than million of Filipinos did not go to school because the crocodiles are stealing the money of our society. And then some of Koreans in our country are racist.] No offense to Koreans but when you're in a foreign country, you respect the locals just the way a when we go to Sokor, we respect your locals and traditions.

\section{Extract 2 P}

wala yan sa school, humahawak ng government natin, tapos ng magagandang school pero corrupt pa din ang government natin, wala yan sa school, nasa tao yan at upbringing ng mga magulang, sa mga foreign student naman, [translation: It's not the school but the people who are our government who graduated in a good school but are corrupt. So it's not about school but people and how they were brought up by their parents and for the foreign students,] keep up the good work and bring what you have learned in the Philippines and dont follow the footstep of many Filipino officials that are corrupt, and for those korean, just compared france education and Philippines and you will find out who are the best which comes to school. cultivate your knowledge in the philippines and serve your country with sincerity...... more power to the philippine schools

\section{Extract 3 P}

bai you are absolutely right! tignan mung manga checkwa alipin tayo sakanila and baba tingin nila saten parang tae. [translation: Friend, you are absolutely right! Look at Chinese, we are slave to them and they look down on us like shit.] soon the korean* $(\mathrm{K})$ will be the same they are very competitive habang ang manga ibang pinoy anak ng anak pero hindi naman kayang paaralin [translation: while Filipinos keep on producing children and could not even afford to give them education. ] how can they compete with this foreigner in the end under privilege pinoy [Filipino] children become slave ! its so obvious now .. shame on our damm* (damn) politician who dont care about us and stupid parents who dont think .

\section{Extract 4 P}

we need employment we need justice to be served very fast specially to ampatuan victims, we need to rise from economic crisis, we need immediate action to the undying problem of hunger and poverty... yes we want a corruption-free country pero (but) it would take a long time bago pa mangyayari yan.. [before it happens]. i'm not saying let's set aside the issues of corruption, pero prang yun na lng kasi inaatupag ng gobyerno eh..dagadagan pang puro grudges and personal sentiments ang sinasabi ng presidente, lalong pinalala ang bangayan, in the end sariling interests and concerns na ang pinanggalingan napakaraming ngyayari sa lipunan na unfair for the common tao..and prang hindi na pinagtuunang pansin. [translation: but it's like that because the government handles it, in addition of the president's grudges and personal sentiments, the dispute is getting worst. In the end, it boils 
down to self interest and concern. There is so much unfairness happens in common people yet nobody pays attention to it. ]

Such translanguaging as part of a lingua franca is used extensively in the Philippines and naturally in blogging. In the online discourse of yahoo Philippines it seems to be used to perform different functions. Several of these functions are to clarify the meaning of the situation and to address the message to specific addressee/audience or to signal inclusion/exclusion from a specific group in the blogging community. As can be seen from the above examples, translanguaging is used in many ways sometimes in quite long sentences through the alternation of one code to another and converging two languages through affixations. The use of borrow or loan words in English and Filipino is also commonly utilized through the insertion of constituents like single words and short phrases.

\section{CONCLUSION}

House wrote:

\begin{abstract}
ELF and multilingualism are not 'either-or' matters, and the use of ELF need not damage linguistic-cultural diversity. The vast majority of ELF speakers are per se bilingual or multilingual speakers, which means that transfer from other languages and code-mixing are common in ELF interactions (House, 2012:174)
\end{abstract}

The fact is that speakers use English in varied forms, and a 'monochrome' standard form, even within a relatively small geographical area such as Singapore and the larger area of the Philippines does not reflect reality. Indeed, ELF speakers do not just adhere to a fixed set of English Native speaker norms but exploit language in creative ways to negotiate communication. Traditional attitudes towards translation have been affected in recent years by factors related to the impact of globalization and new communication technologies. Of particular relevance is the growing use of English as an international language in administration, business and higher education (for example: India, South Africa, as well as Singapore, and The Philippines). that ELF users orientate towards content and exploit their translanguaging resources to get their messages across.

It is true that from the growing research into ELF, we are entering 'uncharted territory' (Mauranen (2012:1). It is 'uncharted' because the globalization of discourse, especially through the internet, makes it necessary to problematize and relativize basic cultural values and orientations such as these which are transmitted and expressed in and through language. This seems particularly true of translation where 'native speaker' norms have been dominant. We need therefore, to examine how language functions in different societies, where language needs adapted to the richly contextualized forms occur in society. These forms emanate from language users' linguistic repertoire but these repertoires no longer belong to a single society or culture (House, 2015)

\section{REFERENCES}

Baker, M. (2006). Translation and Conflict: A Narrative Account. London: Routledge.

Bautista, M. L. S. (2000). Defining Standard Philippine English. It's Status and Grammatical Features. Manila: De La Salle University Press.

Canagarajah, S. (2007). Lingua Franca, Multilingual Communities and Language Acquisition. The Modern Language Journal, 91: pp. 923-939.

Castillo, E. S. (2003). English Language Teaching in the Philippines today. In Ho Wah Kam and Ruth Y.L. Wong (eds.) English Language Teaching in East Asia Today: Changing Policies and Practices (pp. 321-335). Singapore: Eastern Universities Press.

Cogo, A. \& Dewey, M. (2012). Analysing English as a Lingua Franca. A Corpus-driven Investigation. London: Continuum.

Crewe, W. J. (1977). The English Language in Singapore. Singapore: Eastern Universities

Cronin, M. (2003). Translation and Globalization. London: Routledge.

Deocampo, M.F. (2011). The Constraints and Social Functions Influencing Language Switching: A Study of Television Shows in the Philippines. (Unpublished MA Thesis). Assumption University, Bangkok, Thailand.

Deocampo, M.F. (2014). A Cyber-ethnographic Study and Critical Discourse Analysis of Yahoo.ph and Yahoo.sg News Pulse. (Unpublished Doctoral Dissertation). Assumption University. Bangkok, Thailand.

Firth, A. (2009). The Lingua Franca Factor. In J. House (ed.) Special Issue: English Lingua Franca. Intercultural Pragmatics 6(2), pp. 14770

Foley, J. A. (1988). New Englishes: The Case of Singapore. Singapore: Singapore University Press.

Foley, J. A. (1998). Code-switching and learning among young children in Singapore. International Journal of the Sociology of Language. 130, pp. 129-150.

Foley J. A. (2006) English as a lingua franca: Singapore. International Journal of the Sociology of Language 177, (pp. 51-56) .

Foley, J. A. (2014). Ante et Retro Occulata: Looking Back and Looking Forward. International Journal of Innovation in English Language Teaching. 3(1), pp. 73-85. 
Foley, J.A., Kandiah, T., Zhiming, B., Gupta A.F., Alsagoff, L. Lick, H. C., Wee, L., Talib, I. \& Bokhurst-Heng, W. (1998). English in New Cultural Contexts: Reflections from Singapore. Singapore: Oxford University Press.

Garcia, O \& Wei, L. (2014) Translanguaging: Language, Bilingualism and Education. Basingstoke: Palgrave Macmillan

George, C. (2012). Freedom from the Press: Journalism and State Power in Singapore. Singapore: NUS Press

Gorter, D. (2006). Linguistic Landscape: A New Approach to Multilingualism. Clevedon: Multilingual Matters

Gupta, A.F. (1998). A framework for the analysis of Singapore English. In S. Gopinathan,Pakir, W.K. Ho \& V. Saravanan, (eds.) Language, Society and Education in Singapore: Issue and Trends (pp. 199-132). Singapore: Times Academic Press.

Henderson, C. (2002). Philippines capsule in Asia market research. Retrieved from http://www.asiamarketsearch.com/philippines/

House, J. (2012). Translation, Interpreting and Intercultural Communication. In J. Jackson (ed.), Routledge Handbook of Intercultural Communication (pp. 495-510). London: Routledge.

House, J. (2015). Translation Quality Assessment: Past and Present. London: Routledge. International Journal of the Sociology of Language 130, pp. 129-150.

Lim L. (2004). Singapore English: A grammatical description. Amsterdam: John Benjamins.

Llamzon T.A. and K.B. Lee. (1980). Patterns in the acquisition of bilingual ability and language use in three Southeast Asian countries. In Evangelos Afendras (ed), Pattern of Bilingualism. Anthology Series 8. Singapore: SEAMEO Regional Language Centre

Ling, L. E. \& Brown, A. (2005). English in Singapore: An Introduction. McGraw-Hill Education Asia.

Marasigan, E. (1983). Code-switching and Codemixing in Multilingual Societies. Singapore: Singapore University

Mauranen, A. (2012). Exploring EFL: Academic English Shaped by Non-native Speakers. Cambridge: Cambridge University Press.

Nida, E. (1964). Toward a Science of Translation. Leiden, Brill.
Pena. P.S. (2000). Second Language Teacher Education: Where from and Where to? Lecture for the Alice Hollister-Marquardt Memorial Professional Chair in English, The Philippines Normal University, Manila.

Platt, J. \& Weber, H. (1980). English in Singapore and Malaysia: Status; Features: Functions. Kuala Lumpur: Oxford University Press.

Saussure, F. (1959). Course in general linguistics (English trans.) New York: Philosophical Library

Seidlhofer, B. (2011). Understanding English as a Lingua Franca. Oxford: Oxford University

Sibayan, B., \& Gonzalez, A. (1996). Post-Imperial English in the Philippines. In J.A. Fishman, A.W. Conrad and A. Rubal-Lopez (eds.) PostImperial English Status Change in Former British and American Colonies (pp. 19401990). New York: Mouton de Gruyter.

Sibayan, B. P. (1978). Views on Language and Identity: Limited Metro Manila example. In A.Yap, ( ed). Language Education in Multilingual Societies (pp. pp. 2-52). Singapore: Singapore University Press.

Sibayan, B. P. (1994). The role and status of English vis-a- vis Filipino and other languages In the Philippines. In T Kandiah and J Kwan-Terry, (eds). English and Language Planning: A Southeast Asian Contribution (pp. 218-241). Singapore: Times Academic Press.

Son . J. (1998) Culture Philippines Tongue-tied over language.http://www.oneworld.org/ips 2.aug98/0 354 003.html.

Sunga, N. (2003). English Language Teaching and the New Curriculum in The Philippines: The Re-training of English Teachers. In Ho Wah Kam and Ruth Y.L. Wong (eds.) English Language Teaching in East Asia Today: Changing Policies and Practices (pp. 337349). Singapore: Eastern Universities Press.

Tongue, R. K. (1974). The English of Singapore and Malaysia. Singapore: Eastern Universities Press.

Wee, L., Goh, R. B .H., \& Lim, L. (2013). The politics of English: South Asia, Southeast Asia and the Asia Pacific. Amsterdam: John Benjamins.

Widdowson, H. (1994). 'The Ownership of English'. TESOL Quarterly 28, pp. 377-389. 